\title{
REMOVAL OF IRON FROM AQUEOUS SOLUTION BY RICE HUSK: ISOTHERM AND KINETIC STUDY
}

\section{Studi Isothermal Dan Kinetika: Penyisihan Logam Besi Dalam Larutan Menggunakan Sekam Padi}

\author{
Monik Kasman $^{1 \star}$, Shaliza Ibrahim², Salmariza ${ }^{3}$ \\ ${ }^{1}$ Environmental Engineering Department, Engineering Faculty, University of Batanghari \\ Jl. Slamet Riyadi, Broni, Jambi, 36122, Phone/Fax. (0741) 668280 \\ ${ }^{2}$ Civil Engineering Department, Engineering Faculty, University of Malaya \\ ${ }^{3}$ Institution for Research and Standardization of Industry, Padang. \\ * e-mail: emka engineer@yahoo.com
}

Diterima : 8 Oktober 2012, Revisi akhir: 30 November 2012

\begin{abstract}
This work was focused on iron adsorption by rice husk. The use of rice husk for the removal of iron from aqueous solution at different contact time, $\mathrm{pH}$, adsorbent doses and initial iron concentration was investigated. This study was also aimed to recognize the mechanisms that govern iron removal, and to find an appropriate isotherm and kinetic model in batch process. The equilibrium adsorption isotherms have been analyzed by Freundlich and Langmuir model. The pseudo-first, and pseudo-second order kinetic models have been used to investigate the mechanism of adsorption and potential rate controlling steps. The equilibrium data fitted well to Freundlich model and mechanism of adsorption described well to pseudo first order kinetic. The iron adsorption process was highly dependent on $\mathrm{pH}$, dosage and initial concentration dependent. Iron was reduced higher with decrease in iron concentration and increase in rice husk dosage. The suitable contact time for iron removal was found to be 180 minutes.
\end{abstract}

Keyword: adsorption, iron, rice husk, isotherm, kinetic

\section{ABSTRAK}

Fokus penelitian ini adalah adsorpsi besi dengan menggunakan adsorban sekam padi. Eksperimen dilakukan dengan memvariasikan waktu kontak, nilai $\mathrm{pH}$, dosis adsorban dan konsentrasi awal besi. Penelitian bertujuan untuk mengamati mekanisme yang mempengaruhi penyisihan besi dan menemukan model isothermal dan kinetika yang tepat untuk proses adsorpsi besi. Kesetimbangan model isotermal dianalisis dengan model Freundlich dan Langmuir. Model kinetika order pertama dan kedua digunakan untuk mengamati mekanisme adsorpsi dan tahap kontrol kecepatan potensial. Hasil penelitian menunjukan bahwa model adsorpsi yang tepat untuk penyisihan besi adalah model Freundlich dan mekanisme adsorpsi yang sesuai adalah kinetika orde pertama. Proses adsorpsi besi sangat dipengaruhi oleh $\mathrm{pH}$, dosis adsorban dan konsentrasi awal besi. Persentase penyisihan besi meningkat jika konsentrasi awal besi menurun dan dosis adsorban meningkat. Hasil penelitian menunjukan bahwa adsorpsi besi terjadi dengan baik pada waktu kontak sekurang-kurangnya 180 menit.

Kata kunci: adsorpsi, besi, sekam padi, isotermal, kinetika 


\section{INTRODUCTION}

Heavy metal contained in wastewater is a cause of toxic metal contamination of surface, sea and groundwater resources. Iron, is one of heavy metal discharged from industries, tends to accumulate in living organisms, thus becoming a permanent source of hazard to their health and life, and degradation of the environment. Iron has undesirable effects, even if they are present in trace quantities (Alloway \& Ayres, 1993; Klimmek et al., 2001 cit. Feng et al., 2004). Various treatment to reduce heavy metal including chemical precipitation as metal hydroxide (Berbenni et al., 2000), electrocoagulation (Bazrafshan, et al., 2006), reverse osmosis, ion exchange, membrane separation and adsorption have been applied (Kurniawan et al., 2006). However, Adsorption is by far most adaptable and effective method to reduce any contaminants like heavy metal, especially, if adhered with suitable regeneration steps.

Adsorption is a process in which a single or a group of ions/compounds get accumulated on the surface of another solid or liquid. Its process involves a mass transfer operation through which constituents in the liquid phase are transferred to the solid phase (Metcalf \& Eddy, 2003; Kumar et.al, 2004). The substance on which the adsorption occurs is known as adsorbent and the substance which gets adsorbed or accumulated is called adsorbate. Many adsorbents have been tested for the adsorption of iron. Previous research has reviewed the potential use of adsorbents for the removal of iron from aqueous solutions such as clinoptilolite (Oztaz et al., 2008), eggshell (Yeddou et al., 2007) and activated carbon (Okoniewska et al., 2007). However, some researchers have been reported that rice husk showed good result for reducing heavy metal (Mahvi et al., 2005; Ajmal et al., 2003; Vadivelan et al., 2005; Akhtar et al., 2006; Kumar et al., 2006)

Rice husk contains various organic compounds (lignin, cellulose, and hemicelluloses) that might be useful for binding heavy metal ions (IRRI, 2010). Furthermore, it is also considered plentiful product in Southeast Asia, reasonable cost, and reusable byproduct of rice grinding.

The adsorption isotherm was conducted to know the adsorption behavior along with its adsorption characteristics, while the kinetic study was performed to determine the contact time necessary to reach equilibrium concentration of iron in aqueous solution. The study of adsorption kinetics in wastewater treatment is also important as it provides deep understanding of the reaction pathways and the mechanism of adsorption reactions (Ho \& McKay, 1999; Lagergren, 1898 cit. Sag (2002)).

The objective of the present study is to investigate the removal of iron using rice husk from aqueous solution. Batch experiments are carried out for kinetic studies on the removal of iron from aqueous solutions. The influence of various contributing parameters such as $\mathrm{pH}$, adsorbent concentration, contact time, and initial iron concentration is investigated. Three adsorption isotherm models (Langmuir, Freundlich, and Temkin equation) are used to study the fit of the experimental equilibrium data obtained in the study, and two kinetic models are used to evaluate the mechanism of adsorption.

\section{RESEARCH METHODS}

\section{Adsorbent Preparation}

Rice husk was collected from a nearby rice mill in Kuala Selangor, Malaysia. To remove all the dirt particles and impurities, rice husk was washed several times with tap water followed by distilled water. The washed rice husk was then dried at $100^{\circ} \mathrm{C}$ in an oven until constant weight. Then, it was ground to particle size $\leq 600 \mu \mathrm{m}$. The prepared rice husk adsorbent was kept in air tight container at room temperature. It was called rice husk $(\mathrm{RH})$.

\section{Batch Adsorption Studies}

Amount of $4.964 \mathrm{~g}$ ferrous sulfate $\left(\mathrm{FeSO}_{4} .7 \mathrm{H}_{2} \mathrm{O}\right)$ was dissolved in $1000 \mathrm{~mL}$ of distilled water, to prepare stock solution of iron. Certain concentrations of the iron were obtained by further dilutions. The $\mathrm{pH}$ 
of each last solution was adjusted to the required value with diluted and concentrated $\mathrm{H}_{2} \mathrm{SO}_{4}$ and $\mathrm{NaOH}$ solution. All the chemicals used were analytical reagent grade.

Experiment was carried out in batch process and room temperature. An adjusted $\mathrm{pH}$ of $100 \mathrm{~mL}$ of iron aqueous solution in Erlenmeyer flasks was filled with certain raw rice husk. The flasks were agitated in an orbital shaker at $160 \mathrm{rpm}$. Samples were collected at the designed contact time, filtered and analyzed by the Inductively Coupled Plasma Optima Emission Spectrometer (ICP-OES). Adsorption isotherm studies were done using five initial iron concentrations $(20,30$, 40,50 and $60 \mathrm{mg} / \mathrm{L}$ ), with $2 \mathrm{~g} / 100 \mathrm{~mL}$ adsorbent dosage at $\mathrm{pH} 7$ and room temperature. The sample was collected after 4 hours agitation and filtered. To get kinetic model, those three initial concentrations of iron were 20, 40 and 60 $\mathrm{mg} / \mathrm{L}$ and with $2 \mathrm{~g} / 100 \mathrm{~mL}$ adsorbent at $\mathrm{pH}$ 7 was applied, sample was taken every 30 minutes for 4 hours operation. All the experiments were conducted in duplicates and their mean values of iron removal percentage (eq. (1)) are reported here.

$$
Y=\left(\frac{c_{i}-c_{i}}{c_{i}}\right) \times 100
$$

Here, $Y=$ iron removal percentage, $\mathrm{C}_{\mathrm{i}}=$ initial concentration $(\mathrm{mg} / \mathrm{l}), \mathrm{C}_{\mathrm{f}}=$ final concentration $(\mathrm{mg} / \mathrm{l})$.

\section{RESULTS AND DISCUSSIONS}

\section{Effect of pH}

Five $\mathrm{pH}$ values for separate experiments of $40 \mathrm{mg} / \mathrm{L}$ iron concentration to $1 \mathrm{~g}$ adsorbent dosage and 150 minutes contact time were performed to examine the effect of $\mathrm{pH}$ and to ensure the most suitable $\mathrm{pH}$ value. The $\mathrm{pH}$ parameter has been identified as one of the most important parameter that is effective on metal adsorption (Mahvi et al., 2005; Ajmal et al., 2003; Akhtar et al., 2006; Kasman \& Ibrahim, 2010). It is directly related with competition ability of hydrogen ions with iron ions to active sites on adsorbent surface. The effect of $\mathrm{pH}$ on the adsorption of iron onto $\mathrm{RH}$ showed in Figure 1 which notices that the removal of iron on $\mathrm{RH}$ became higher as the $\mathrm{pH}$ value increased. The removal became constant at $\mathrm{pH}$ value between 7 and 9 or in neutral or alkali solution.

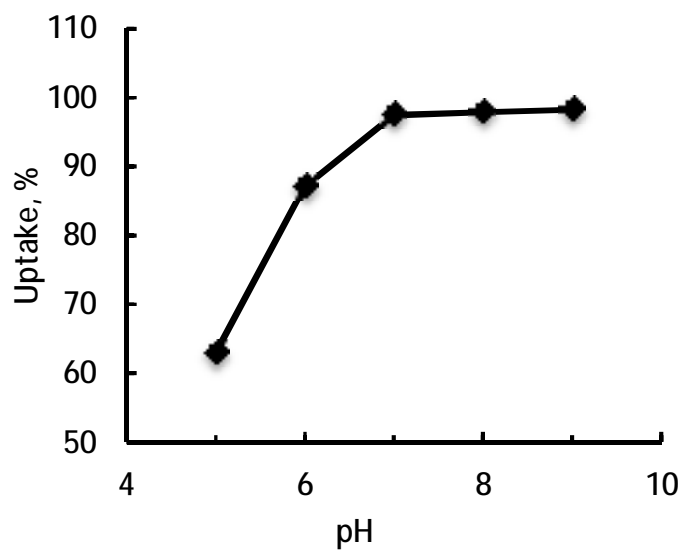

Figure 1: Effect of $\mathrm{pH}$ on removal of iron

\section{Effect of adsorbent dosage}

Five adsorbent dosages were varied in this experiment combined with $\mathrm{pH}$ value of 7 , contact time of 150 minute, certain iron initial concentration.

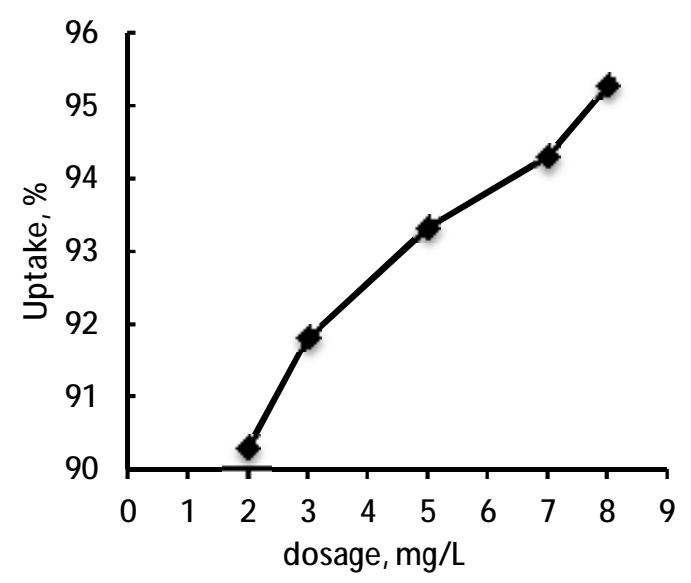

Figure 2: Effect of adsorbent dosage on removal of iron

The removal of iron using $\mathrm{RH}$ increased as the adsorbent dosage increased. Similar result was also reported by Ajmal et al (2003), Mahvi et al (2005), 
Akhtar et al (2006), and Kasman \& Ibrahim (2010). However, value of suitable dosage was still not found in this study. As shown by trend of curve in Figure 2 which it becomes higher as dosage bigger. To achieve better results, continues research is recommended.

\section{Effect of initial concentration}

Three initial iron concentrations were 20,40 and $60 \mathrm{mg} / \mathrm{L}$ treated with $7,5 \mathrm{~g}$ of adsorbent dosage, and 150 minutes of contact time for iron adsorption. Figure 3 reveals that adsorption process for iron was better in lower initial concentration. Yeddou (2007) found that the increase of initial iron concentration, adsorption capacity increased directly.

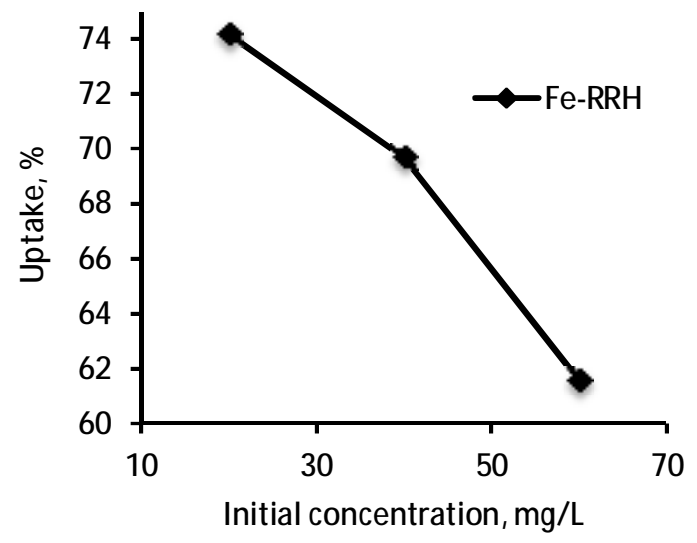

Figure 3: Effect of initial concentration on removal of iron

\section{Effect of contact time}

The rate of adsorption is important to design batch experiment. Thus, the effect of contact time on iron adsorption was investigated. The experiment was done for 240 minutes (4 hours) and sample was collected after 60 minutes, 120 minutes, 150 minutes, 180 minutes and 240 minutes processes. The removal of iron was decreased the contact time increased but become constant after 180 minutes. For further experiment, 60 minutes is considerably suitable for iron adsorption process as reported previous report for similar result in reducing heavy metal using different kind of adsorbents (Ajmal et al., 2003).

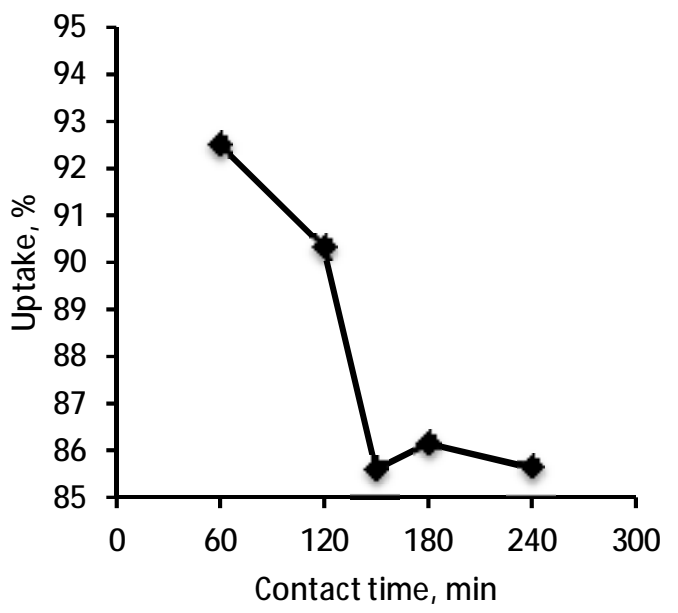

Figure 4: Effect of contact time on removal of iron

\section{Isotherm and kinetics study for iron adsorption}

Isotherm of adsorption provides description of adsorbent capacity used, is $\mathrm{RH}$. It expresses the surface properties and affinity of $\mathrm{RH}$. In this study, the adsorption isotherms were investigated using two equilibrium models, which are namely the Langmuir and Freundlich models. Freundlich and Langmuir isotherm expression is given by the following equations (Freundlich et al., 1906; Langmuir et al., 1916 quoted by Yeddou et al., 2007):

Freundlich:

$$
\mathrm{q}_{\mathrm{e}}=\mathrm{K}_{\mathrm{f}} \cdot \mathrm{C}_{\mathrm{e}}^{1 / \mathrm{n}}
$$

Where $K_{f}$ and $n$ are the Freundlich constants characteristic of the system. Equation (2) can be linearized in a logarithmic form and the Freundlich constants can be determined.

$$
\ln q_{e}=\ln K_{f}+(1 / n) \ln C_{e}
$$

Langmuir:

$$
\mathrm{q}_{\mathrm{e}}=q_{o} \frac{b C_{e}}{1+b C_{e}}
$$


Where $q_{e}$ is the equilibrium iron concentration on the adsorbent $(\mathrm{mg} / \mathrm{g}), \mathrm{C}_{e}$ is the equilibrium iron concentration in the solution $(\mathrm{mg} / \mathrm{L}), \mathrm{q}_{\mathrm{o}}$ is the monolayer sorption capacity of the sorbent $(\mathrm{mg} / \mathrm{g})$, and $\mathrm{K}_{\mathrm{L}}$ is the Langmuir sorption constant $(\mathrm{L} / \mathrm{mg})$ related with the free energy of sorption.

Table 1. Freundlich and Langmuir constants

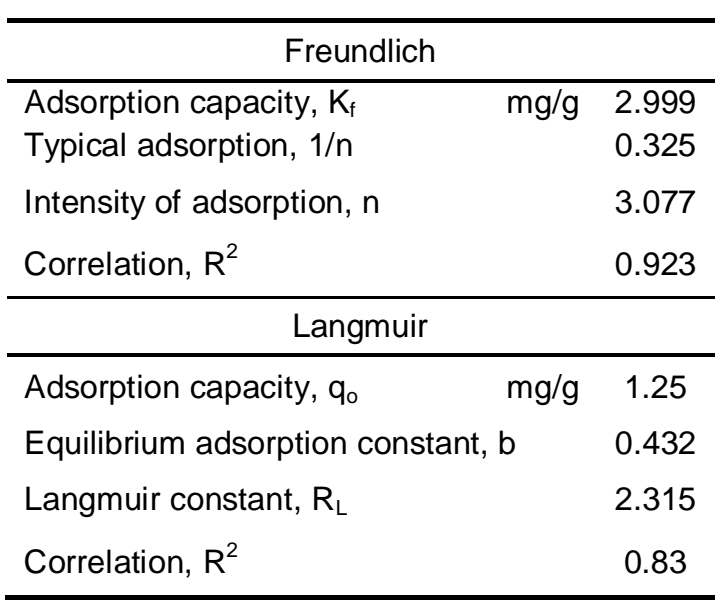

These two models have been successfully applied to the iron adsorption processes. The results are showed in Table 1 along with their figures in Figure 5. The values of Langmuir constants $R_{L}$ and $b$ were obtained from the intercept and slope of the plot between (Ce/qe) vs. (1/Ce) presented in Figure 5(b).

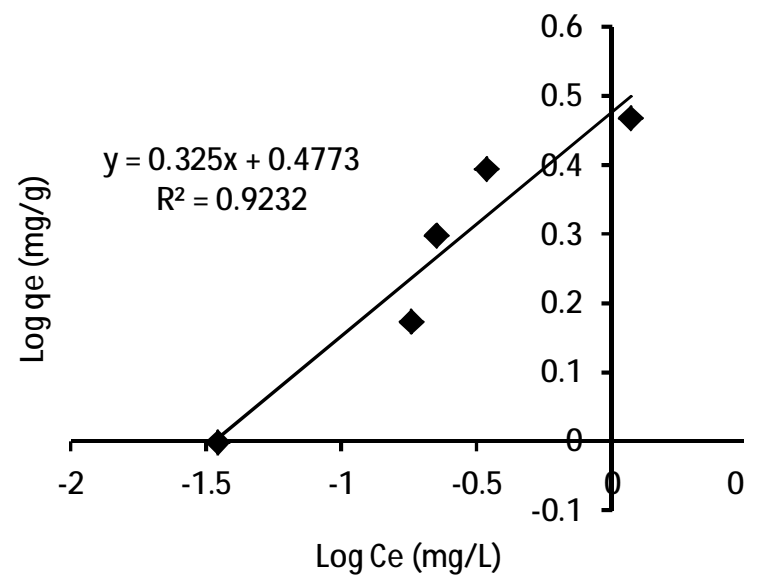

(a)

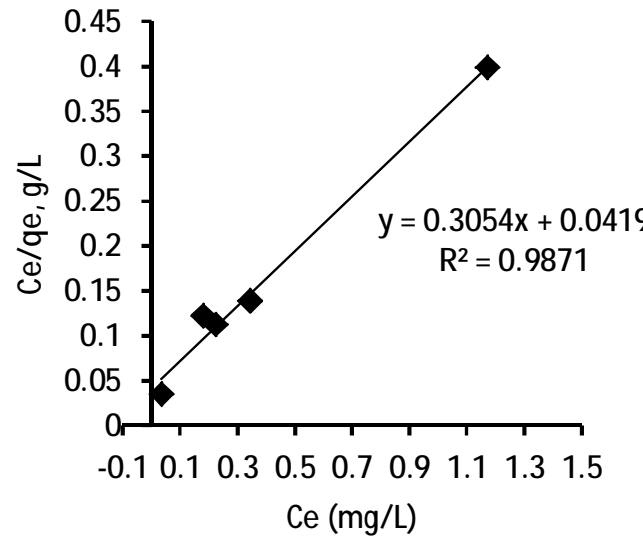

(b)

Figure 5: Freundlich (a) and Langmuir (b) isotherm model

The obtained value of $1 / n$ in Freundlich model for $\mathrm{RH}$ in iron adsorption are less than 1, while Langmuir model are $0<\mathrm{RL}<1$. It indicates that the adsorption process is favorable. The kinetic adsorption results showed in this discussion is only the pseudo second order kinetic since this order is stronger than the pseudo first order kinetic. The values of kinetic parameters are presented in Table 2.

In order to analyze the adsorption kinetic of iron, the pseudo first order and pseudo second order were applied to data. Pseudo fist order equation is expressed as follows:

$$
\frac{d q_{t}}{d t}=k_{1}\left(q_{e}-q_{t}\right)
$$

Where $q_{e}$ and $q_{t}$ are the sorption capacity at equilibrium and at time $t$, respectively $(\mathrm{mg} / \mathrm{g})$ and $\mathrm{k}_{1}$ is the rate constant of pseudo-first order sorption $\left(\mathrm{min}^{-1}\right)$. After integration and applying boundary conditions from $t=0$ to $t=t$ and $q_{e}=0$ to $q_{t}$ $=q_{t}$, the integrated form of equation becomes:

$$
\log \left(q_{e}-q_{t}\right)=\log q_{e}-\frac{k_{1}}{2.303} t
$$


The pseudo-second order equation of the adsorption rate is expressed as follows:

$$
\frac{d q_{t}}{d t}=k_{2}\left(q_{o}-q_{e}\right)^{2}
$$

Here $q_{e}$ and $q_{t}$ are the sorption capacity at equilibrium and at time $t$, respectively and $k_{2}$ is the rate constant of pseudo-second order sorption $\left(\mathrm{min}^{-1}\right)$. After integrating and applying boundary conditions from $t=0$ to $t$ $=t$ and $q_{0}=0$ to $q_{e}=q_{e}$, the integrated form of equation becomes:

$$
\frac{t}{q_{e}}=\frac{1}{k_{2} q_{o}^{2}}+\frac{1}{q_{o}} t
$$

For kinetic, Figure 6 (a dan b) depicts the plot of adsorption capacity at equilibrium time versus contact time for iron desorption using $\mathrm{RH}$. Moreover, values of the pseudo-first order and pseudo second order rate constant $(\mathrm{K})$ and the adsorption capacity $\left(q_{e}\right)$ computed from the slope and intercept as well as the correlation values from iron are presented in Table 2. It was observed that the correlation values of iron was close to 1 which confirms that the adsorption process follows a pseudosecond-order mechanism.

Overall, it can be seen that the values of $\mathrm{K}$ and $\mathrm{q}_{\mathrm{e}}$ increased with increase in initial concentration as similar reported by Vadivelan \& Kumar (2005).

Table 2: Kinetic parameters for the iron adsorption using $\mathrm{RH}$

\begin{tabular}{ccccccc}
\hline $\begin{array}{l}\text { Initial } \\
\mathrm{Fe}(\mathrm{II})\end{array}$ & \multicolumn{3}{c}{ Pseudo 1st order } & \multicolumn{3}{c}{ Pseudo 2nd order } \\
\cline { 2 - 7 } $\mathrm{mg} / \mathrm{L}$ & $\begin{array}{c}\mathrm{K}_{1} \\
\mathrm{~g} / \mathrm{min} . \mathrm{mg}\end{array}$ & $\begin{array}{c}\mathrm{qe} \\
\mathrm{mg} / \mathrm{g}\end{array}$ & $\mathrm{R}^{2}$ & $\begin{array}{c}\mathrm{K} \\
\mathrm{g} / \mathrm{min} . \mathrm{mg}\end{array}$ & $\begin{array}{c}\mathrm{qe} \\
\mathrm{mg} / \mathrm{g}\end{array}$ & $\mathrm{R}^{2}$ \\
\hline & 0.0184 & 1.112 & 0.643 & 19.336 & 0.993 & 1 \\
20 & 0.0230 & 1.884 & 0.576 & 1317.5 & 1.988 & 1 \\
40 & 0.0392 & 2.655 & 0.566 & 13.652 & 2.967 & 1 \\
60 & & & & & & \\
\hline
\end{tabular}

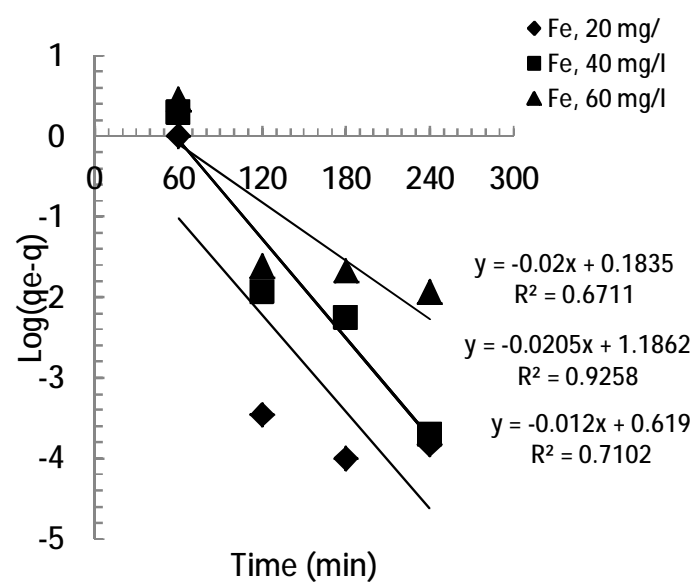

(a)

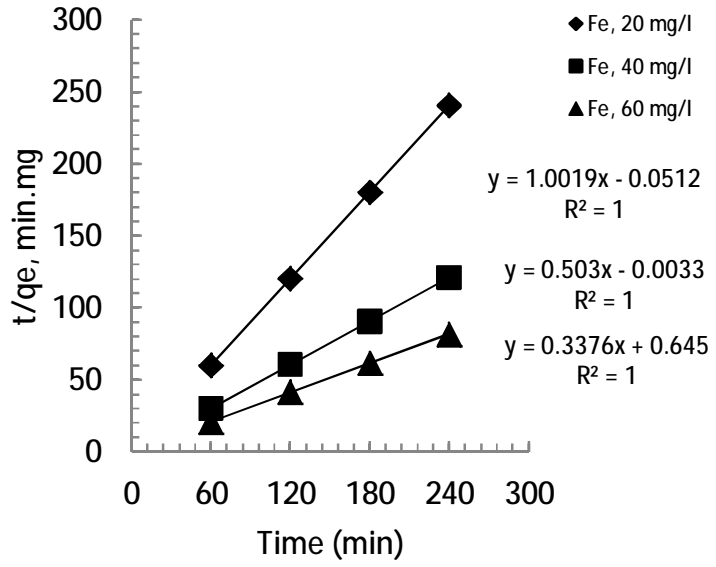

(b)

Figure 6: Pseudo first order (a) and pseudo second order (b) kinetic for iron adsorption by $\mathrm{RH}$ 


\section{CONCLUSIONS}

Adsorption studies of iron removal by rice husk from aqueous solution have been carried out varying $\mathrm{pH}$, adsorbent dosage, initial concentration and contact time. The study noticed that rice husk can reduce iron in range of obtained results may be summarized as follows:

(1) The $\mathrm{pH}$ variation studies figured out that the iron adsorption process is highly $\mathrm{pH}$ dependent. The optimum $\mathrm{pH}$ range for the removal was recommended to be neutral (7-9).

(2) Increase in adsorbent dosage leads to increase in iron adsorption due to increased number of adsorption sites. Maximum uptake of iron was obtained at adsorbent dosage of $8 \mathrm{mg} / \mathrm{L}$. But, further experiment is needed to attain adsorption equilibrium process.

(3) The amount of iron was removed lower with increase in initial iron concentration. Similar condition was found in effect of contact time to iron adsorption. Iron was adsorbed lower as the increase of contact time but become constant after 180 minutes which indicates equilibrium phase achieved.

(4) Equilibrium data fitted very well in a Freundlich isotherm equation, confirming adsorption capacity of iron onto rice husk with adsorption capacity of $2.999 \mathrm{mg} / \mathrm{g}$.

(5) The rate kinetics for adsorption of iron was best described by pseudo second order model.

\section{ACKNOWLEDGEMENT}

Financial assistance from IPPP Grant of University of Malaya is grateful acknowledged.

\section{REFERENCES}

Ajmal M., Khan Rao R.A., Anwar S., J. Ahmad, R. Ahmad. 2003. Adsorption studies on rice husk: removal and recovery of $\mathrm{Cd}(\mathrm{II})$ from wastewater, Bioresource Technology 86: 147-149.

Akhtar, M.M.I. Bhanger, S. lqbal and Hasany S.M. 2006. Sorption potential of rice husk for the removal of 2,4dichlorepheno from aqueous solutions: Kinetic and thermodynamic investigations, Journal of Hazardous Materials B128: 44-52.

Bazrafshan E., Mahvi A. H., Nasseri S., Mesdaghinia A. R., Vaezi F., Nazmara Sh. 2006. Removal of Cadmium from Industrial Effluents By Electrocoagulation Process Using Iron Electrodes. Iran. J. Environ. Health Sci. Eng 3 (4): 261-266.

Berbenni P., Pollice A., Canziani R., Stabile L. and Nobili F. 2000. Removal of iron and manganese from hydrocarboncontaminated Ground waters, Bioresource Technology 74 109-114.

Feng, Q. Ling, G. Fuzhong, S. Sugita M. Shoya and Masami. 2004. Adsorption of lead and mercury by rice husk ash, Journal of Colloid and Interface Science 278: 1-8.

IRRI (International Rice Research Institute). 2010. Rice husk. Rice Knowledge Bank, article retrieved at April 25, 2010 from

http://www.knowledgebank.irri.org/rkb/i ndex.php/rice-milling/byproducts-andtheir-utilization/rice-husk

Kasman M. \& Ibrahim S., 2010. Adsorption of iron(II) from aqueous solution by sodium hydroxide rice husk : response surface methodology and isotherm study. Proceeding of International Conference on Environmental Science and Technology. Bangkok, Thailand.

Kumar U., and Bandyopadhyay M. 2006. Fixed Bed Column Study for Cd (II) Removal From Wastewater Using Treated Rice Husk. Journal of Hazardous Waste Materials B129 253 $-259$.

Kurniawan T.A., Chan G.Y.S., W.H., Babel S.. 2006. Low Physicochemical treatment techniques for wastewater laden with heavy metals. Chem. Eng. Journal 118: 83-98. 
Mahvi A.H., Alavi N. and Maleki A. 2005. Application of Rice Husk and Its Ash in Cadmium Removal from Aqueous Solution. Pakistan Journal of Biological Sciences 8 (5): 721 - 725.

Metcalf \& Eddy. 2003. Wastewater Engineering: Treatment and Reuse. McGraw-Hill Higher Education. New York, USA.

Okoniewska E., Lach J., Kacprzak M., and Neczaj E. 2007. The removal of manganese, iron and ammonium nitrogen on impregnated activated carbon. Desalination 206: 251-258.

Oztas N.A., Karabakan A., Topal O. 2008. Removal of $\mathrm{Fe}(\mathrm{III})$ ion from aqueous solution by adsorption on raw and treated clinoptilolite. Microporous and Mesoporous Materials 111: 200-205.

Sag.Y \& Y. Aktay.2002. Kinetic studies on sorption of $\mathrm{Cr}(\mathrm{VI})$ and $\mathrm{Cu}$ (II) ions by chitin, chitosan dan Rhizopus arrhizus. Biochemical Engineering Journal 12: 143-153.

Vadivelan, V., \& Kumar, K. V. 2005. Equilibrium, kinetics, mechanism, and process design for the sorption of methylene blue onto rice husk. Journal of Colloid and Interface Science, 286, $90-100$.

Yeddou, and A. Bensmaili. 2007. Equilibrium and kinetic modeling of iron adsorption by eggshells in a batch system: effect of temperature. Desalination 206: 127-134. 